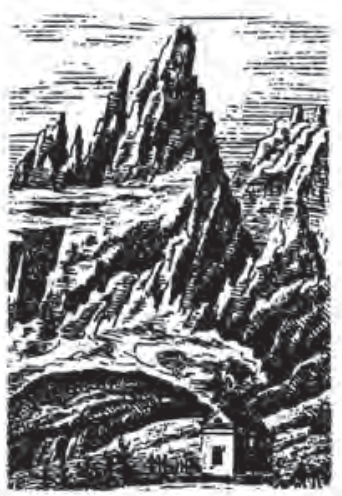

\author{
Katarzyna Tałuć \\ ORCID: 0000-0001-8944-6209 \\ Uniwersytet Śląski \\ katarzyna.taluc@us.edu.pl
}

https://doi.org/10.19195/2084-4107.13.24

\title{
Idealizacja gór w dyskursie prasowym lat międzywojennych
}

Słowa-klucze: góry, prasa dwudziestolecia międzywojennego, idealizacja, wychowanie narodowe

Keywords: mountains, inter-war press, idealisation, national education

\section{Idealisation of the mountains in the press discourse of the inter-war period}

\section{Summary}

The inter-war period in the history of Poland was a time of rebuilding Poland's statehood in all dimensions, including identity and axiology, which was to be reflected in new model citizens aware of their duties to their homeland. Discussions about the axiological foundation of educational ventures in the reborn Poland were part, even before the regaining of independence, of broader disputes over ideology, worldview as well as aesthetics. The model citizen was discussed during meetings of various societies or in the press. What is particularly evident in press publications, especially those appearing when the final borders of Poland were being established, is the interpenetration of political, educational and aesthetic topics. The aim of the article is to present the tools and methods used to idealise the mountains in tourism periodicals and daily press from 1918-1922 as well as the reasons 
why the mountains were functionalised. This analysis is the basis for an attempt to describe the cause and effect links between forms of mountain idealisaiton and, for example, aesthetic categories used in Jan Buthak's concept of homeland photography.

Prasa okresu dwudziestolecia międzywojennego wychodząca na terenie Rzeczypospolitej była szczególnego rodzaju lustrem, w którym odbijały się wszystkie spory na temat kształtu odrodzonego państwa i powinności jego obywateli ${ }^{1}$. Wśród owych dyskusji należy wymienić między innymi te obejmujące problematykę wychowawczą w wymiarze ideologicznym czy estetycznym. Autorzy wypowiedzi drukowanych na łamach czasopism nie poprzestawali tylko na informowaniu czytelników o otaczającej ich rzeczywistości. Prasa stawała się doskonałym narzędziem służącym propagowaniu konkretnych idei, poglądów, przekonywaniu do zaakceptowania określonej wizji, której ramy nadawało pióro dziennikarskie.

Celem autorki artykułu jest analiza, przy zastosowaniu narzędzi właściwych badaniom literaturoznawczym (na przykład geokrytyce) i prasoznawczym, wypowiedzi zamieszczonych w wybranych tytułach czasopism krajoznawczo-turystycznych oraz prasy codziennej pod kątem funkcji, jakie zgodnie z zamierzeniami autorów i/lub redaktorów miały owe teksty pełnić. Badania ograniczono do lat 1918-1922, a więc do okresu kształtowania się granic Rzeczypospolitej, ponieważ burzliwe wówczas wydarzenia naznaczone walką zbrojną znalazły odzwierciedlenie $\mathrm{w}$ artykułach drukowanych na łamach prasy będącej na początku XX wieku masowym medium komunikacyjnym o najszerszym zasięgu oddziaływania. W celu wykazania źródeł sygnalizowanych koncepcji lub ich kontynuacji w niektórych przypadkach wskazane granice chronologiczne zostały przekroczone. W grupie interesujących autorkę czasopism znalazły się: „Ziemia”2 i „Orli

${ }^{1} \mathrm{Na}$ temat historii prasy lat 1918-1939 powstała już bogata literatura. Są to opracowania zarówno syntetyczne, jak i szczegółowe, koncentrujące się na przykład na omówieniu jednego tytułu prasowego. Bibliograficzne spisy prac, obejmujące między innymi czasopisma z wymienionego okresu, regularnie drukuje „Rocznik Historii Prasy Polskiej”.

2 Pierwszy numery „Ziemi” ukazał się z datą 1 stycznia 1910 roku; nosił podtytuł „,Tygodnik Krajoznawczy Ilustrowany”. Inicjatorem pisma był Kazimierz Kulwieć, wiceprezes PTK. Na walnym zebraniu członków towarzystwa 27 lutego 1910 roku jednogłośnie podjęto uchwałę, na mocy której „Ziemia” stała się organem wydawniczym PTK. Oprócz Kulwiecia w skład pierwszej redakcji weszli: Stanisław Thugutt, jako sekretarz, i Mikołaj Wisznicki, pełniący funkcję ilustratora i kierownika artystycznego. Do wybuchu I wojny światowej, mimo trudności przede wszystkim finansowych, wyszły trzydzieści dwa zeszyty. Kolejny łączony numer (33-35) ukazał się po pięcioletniej przerwie z datą 8 sierpnia 1919 roku. W ostatnim numerze z 1919 roku redakcja zapowiedziała zmianę rytmu ukazywania się pisma. Począwszy od 1920 roku, „Ziemia” miała być miesięcznikiem. Jeszcze dwukrotnie, zanim wybuchła II wojna światowa, periodyk zmieniał częstotliwość ukazywania się. Od stycznia 1926 roku był dwutygodnikiem, a od 1932 roku pismo ponownie wydawano raz w miesiącu. Zmianom ulegał również skład redakcji, przy czym przez dłuższy czas, do 1926 roku, osobą mającą znaczący wpływ na kształt pisma był jej pierwszy redaktor i wydawca — Kazimierz Kulwieć. Później, do 1939 roku, pismem kierowali kolejno: Aleksander Janowski, Regina Danysz-Fleszarowa, Konrad Górski, Jerzy Remer, ponownie Janowski i Aleksander Patkowski. Zob. W.A. Wójcik, „Ziemia”. Od PTK do PTTK, „Ziemia” 61, 2010, s. 28. 
Lot”3 - sygnowane przez Polskie Towarzystwo Krajoznawcze (dalej: PTK), adresowane do różnych grup czytelników, na przykład „Orli Lot” był czasopismem młodzieżowym. Oprócz czasopism specjalistycznych wzięto pod uwagę gazety: „Gwiazdkę Cieszyńską"4 i „Gazetę Podhalańską"5. Wybór ten został podyktowany trwałością i zasięgiem terytorialnym obu tytułów, czego implikacją była docelowa grupa odbiorców, najbardziej zainteresowanych informacjami o wydarzeniach bezpośrednio ich dotyczących, między innymi o przebiegu południowej granicy powstającego państwa polskiego. Zestawienie dwóch typów pism, specjalistycznych i gazet, ze względu na różnice w zakresie funkcji, poruszanej tematyki, używanych gatunków wypowiedzi i języka, cech formalno-wydawniczych wydaje się ryzykowne. Przeprowadzone badania wybranego materiału źródłowego pozwoliły jednak wykazać podobieństwa w sposobach kreowania obrazu przestrzeni górskiej w dyskursie prasowym w obrębie tych dwóch grup pism.

Język wypowiedzi w polskich czasopismach, zwłaszcza tych wychodzących na terenie Górnego Śląska oraz Śląska Cieszyńskiego w okresie kształtowania się zrębów przyszłego województwa śląskiego, odznaczał się wysokim stopniem ideologizacji. Można zauważyć na przykład nasycenie tekstów metaforyzacją, alegoryzacją, stereotypizacją, trawestacją. Stopień nasycenia wypowiedzi słownych oraz wizualnych wskazywał na konwencjonalne (patetyczne, wzniosłe, komiczne) przedstawianie konkretnego tematu, ukierunkowując jednocześnie jego recepcję. Podobnie jak teksty literackie i paraliterackie z lat powstań śląskich i plebiscy-

${ }^{3}$ Pierwszy numer „Orlego Lotu”, łączony (1-2), z podtytułem „Miesięcznik Krajoznawczy dla Młodzieży”, ukazał się w 1920 roku (kwiecień-maj). W apelu skierowanym do czytelników nakreślono zadania, jakie pismo, a właściwie jego odbiorcy, winno realizować: „Oddając pierwszy numer czasopisma, poświęconego krajoznawstwu, do rąk młodzieży, pragniemy rozdmuchać tę iskrę, która w młodocianym rozpala się wieku, iskrę miłości Ojczyzny, miłości wszystkiego, co nasze, ziemi naszej, jej historii, zabytków i ludu polskiego. Poznać, aby ukochać — oto hasło nasze. Z tym hasłem idziemy do Was, Młodzieży Polska. Pragniemy, aby w czasie wolnym od nauki wszystkie ziemie polskie zaroiły się od gromadek młodych krajoznawców, by do nich przemówić mogły wszystkie góry i rzeki, wszystkie miasta, wsie, kościoły i zamki, chata polska i lud polski, by mogły przemówić swoją przeszłością, by mogły opowiadać im swe dole i niedole, i ich życie obecne, żeby wszystko śpiewało im pieśń zwycięstwa i swobody, by odczuć i zrozumieć mogli, że ziemia ta i wszystko na niej to nasze, to polskie, zdobyte i wywalczone długowiekową pracą naszą i przodków naszych". W następnym numerze - trzecim — w winiecie figuruje już rozbudowany tytuł, czyli „Orli Lot. Miesięcznik Krajoznawczy dla Młodzieży”, który powstał z inspiracji Pieśniq o ziemi naszej Wincentego Pola. Redaktorem naczelnym miesięcznika, od pierwszego do ósmego numeru z 1938 roku, był Leopold Węgrzynowicz, a następnie, do wybuchu II wojny światowej, Tadeusz Seweryn. Zob. też o powojennych losach pisma A. Czarnowski, Leopold Wegrzynowicz - organizator krajoznawstwa wśród młodzieży, Warszawa 1987.

4 „Gwiazdka Cieszyńska” to tygodnik wydawany w latach 1851-1939; po 1906 roku dwutygodnik. Założony przez Pawła Stalmacha. W okresie międzywojennym (1902-1929) redagowany między innymi przez Józefa Londzina.

5 „Gazeta Podhalańska” — w latach 1913-1935 tygodnik; w latach 1918-1920 faktycznym redaktorem był Juliusz Zborowski. 
tu, kształtujące „mit męczeństwa, bohaterstwa Ślązaka”, podsycające, z jednej strony, uczucia pozytywne - miłość, oddanie, poświęcenie dla sprawy polskiej, z drugiej strony, uczucia negatywne - nienawiść, pogardę wobec dotychczasowych ciemiężców (Niemców), tak i część wypowiedzi drukowanych na łamach pism krajoznawczo-turystycznych miała wywołać zbliżone reakcje.

Przed wybuchem I wojny światowej w atmosferze findesieclowego napięcia, rozdrażnienia i jednocześnie rozprężenia różne organizacje, stowarzyszenia działające na ziemiach polskich, chcąc zmobilizować swoich członków do działań, inicjowały akcje, które miały poruszyć „strukturę duchową”. W 1911 roku w dwudziestym trzecim numerze „Ziemi” wydrukowano zapowiedź zorganizowania wystawy zatytułowanej „Krajobraz polski”. Wyliczając szczegółowe cele akcji, na początku zapowiedzi zaakcentowano: „Lecz krajobraz ma i inne niemniej doniosłe znaczenie - on decyduje o pięknie przyrody ojczystej, on jest źródłem najczęstszych wzruszeń estetycznych, z niego rodzą się wszelkie produkcje artystyczne" ". Wyjątek ten dowodzi, że akcja zainicjowana przez Polskie Towarzystwo Krajoznawcze miała za zadanie nie tylko swoistego rodzaju inwentaryzację ingrediencji krajobrazu, lecz także wskazanie jego funkcji, a właściwie zmienności tej funkcji w życiu człowieka rozumianego jako integralna część owej przestrzeni. Znamienne jest nacechowanie emocjonalne języka wypowiedzi. W tekst o charakterze informacyjnym wpisano takie zwroty, jak: „,przyroda ojczysta”, „krajobraz polski", ewokujące jednoznacznie pozytywne odczucia. W ostatnim zdaniu natomiast redakcja, zmieniając przymiotnik ,polski” na toponim „Polski”, odkryła faktyczny sens i cel wystawy. Wystawa, poprzez zaprezentowanie zgromadzonych rekwizytów unaoczniających piękno ojczystego krajobrazu, miała wywołać, jak mówił podczas otwarcia Kazimierz Kulwieć, „podniosłe wrażenia”, skutkujące „obroną piękna naszego kraju”8. Prezes PTK z oczywistych — cenzuralnych — względów posługiwał się językiem ezopowym, ale jego przemówienie było interpretowane nie tylko jako apel o ochronę pierwotnego stanu przyrody, lecz także jako wezwanie do pielęgnowania w sobie poczucia tożsamości i przywiązania do wszystkiego, co definiuje przymiotnik „ojczysty”.

Pokłosiem wystawy „Krajobraz polski” był między innymi numer specjalny „Ziemi”, numer dziewiąty z 1912 roku, poświęcony zagadnieniom krajobrazu. Szczególne znaczenie dla rozumienia pojęć „krajobraz ojczysty”, „krajobraz narodowy", a także thumaczenia sensu zapisu krajobrazu miał artykuł Jana Bułhaka, fotografa, teoretyka sztuki, który krajobraz nie tyle widział, co czuł; przeżywał sensualistycznie. Fotografia była zatem efektem uczuciowego „przepracowania” krajobrazu:

${ }^{6}$ Zob. K. Heska-Kwaśniewicz, ,, Wyznanie narodowe Ślaska”. Teksty literackie i paraliterackie w drukach okresu powstań i plebiscytu na Górny Ślasku, Katowice 1999, s. 112.

7 Wystawa „Krajobraz polski”, „Ziemia” 2, 1911, nr 23, s. 390. Zob. również W. Skowron, Krajobraz polski w centrum zainteresowania Polskiego Towarzystwa Krajoznawczego - wystawy fotograficzne, „Ziemia” 61, 2010, s. 219.

8 K. Kulwieć, Na otwarcie wystawy, „Ziemia” 3, 1912, nr 11, s. 176. 
nie może być większego ukojenia i bardziej radosnego uszczęśliwienia jak samotne i długie obcowanie z przyrodą we wszystkich jej przemianach i nastrojach, że do szczęścia nieraz wystarczyć może zielona i kwietna polana na skraju lasu lub szeleszczące złoto żytniego łanu; że wieczór letni różany i śpiewny w miękkich i nikłych tęczowych kolorach przynosi najwyższy spokój i duszy zmęczonej rozlewne uciszenie. Tę radość przeczystą i górną potęguje i do wyżyn już nieziemskich wznosi zdolność odtwórcza. Czuć pełnym sercem piękno swej ziemi i móc je oddawać w barwach, kształtach, w światłach i cieniach — to szczęścia ludzkiego szczyt najwyższy $[\ldots]^{9}$.

Dla Bułhaka, z racji zainteresowań i pasji, widzenie odgrywało główną rolę w postrzeganiu przestrzeni. Przytoczony cytat dowodzi wyjścia poza paradygmat wzrokocentryczny. „Szeleszczące łany”, „śpiewny wieczór” wskazują na włączenie w deskrypcję krajobrazu elementów sonotopografii. W tekstach Bułhaka na temat postrzegania przestrzeni obecne są echa romantycznego widzenia krajobrazu, a więc eksponującego opis uczuć, którego słowny zapis przestrzeni był ostatecznie tłem, tak jak klisza czy błona fotograficzna pozwalające na wizualną rejestrację obrazu były tylko ramami dla sensu (idei) fotografii. Bułhak przekonywał, że warunkiem osiągnięcia artyzmu w fotografii pejzażowej jest zaistnienie, aby posłużyć się terminologią geokrytyki, mediacji. Człowiek dopiero po uświadomieniu sobie więzi, jaka łączy go z otaczającą przestrzenią, owej symbiozy, będzie w stanie

pojmować, iż nie uchwyci tajemnej wewnętrznej mowy przyrody ten, kto bada tylko, co się wśród niej znajduje, zamiast słuchać, jak ona przemawia, zamiast patrzeć, jak się ona przedstawia w swoich wielkich żywiołowych rysach i liniach. Zaczyna [człowiek - K.T.] pojmować, iż w niej, jak na całym obszarze odczuwania ludzkiego, nie ma rzeczy pięknych lub brzydkich, a są tylko wyraziste, symbolicznie odpowiadające stanom zrosłej z nią [przyrodą - K.T.] duszy [... $]^{10}$.

We wzorce postrzegania przestrzeni, popularyzowane przez malarstwo, literaturę romantyzmu i korespondujące z Kantowską teorią wzniosłości, Bułhak wpisał treści wypływające $\mathrm{z}$ aktualnych dyskusji na temat kondycji i przyszłości narodu polskiego. Poglądy fotografa, obejmujące problematykę zaangażowania fotografii w działania pozaestetyczne, znalazły pełny wyraz w latach trzydziestych XX wieku w kodyfikowanym przez niego i propagowanym Programie Fotografii Ojczystej ${ }^{11}$. Bułhak, pochodzący z Wileńszczyzny, pozostawił w swoim dorobku, zwłaszcza tym sprzed 1939 roku, najwięcej prac poświęconych jego rodzinnej

9 J. Bułhak, Krajobraz i fotografia, „Ziemia” 3, 1912, nr 9, s. 139.

10 Ibidem, s. 142-143.

11 Zob. M. Szymanowicz, W poszukiwaniu ,narodowości w fotografice”, „Artium Quaestiones” 28, 2017, s. 78-82; idem, Topografia sukcesu, „Artium Quaestiones” 17, 2006, s. 83-99, https:// repozytorium.amu.edu.pl/handle/10593/11099 (dostęp: 8.06.2018). 
krainie, umiejętnie wykorzystując elementy mitu sarmackiego-szlacheckiego w konstrukcji wizualnego obrazu pejzażu ojczystego.

Sposoby ujęcia, rejestrowania elementów przestrzeni, a przede wszystkim nadawania im pozaestetycznych funkcji wypracowane przez Bułhaka były obecne także w tekstach innych autorów - tekstach poświęconych innym typom krajobrazu, między innymi górom. Przykładem tego są artykuły dotyczące Spiszu i Orawy - obszarów, których przynależność państwowa wywołała spór i walkę zbrojną między Polską a Czechosłowacją w latach 1918-1920. W 1920 roku cały czwarty numer „Ziemi” poświęcono temu spornemu terenowi. Mimo że redakcja nie podała powodów zwiększenia objętości rzeczonego numeru i rezygnacji w nim ze stałych rubryk, między innymi sprawozdań, to każdy czytelnik z łatwością odczytał intencje przyświecające przygotowaniu zeszytu. Wszystkie materiały składające się na numer czwarty mogły być wykorzystane w akcjach propagandowych, mających na celu udowodnienie praw Polski do Spiszu i Orawy. Już same nazwiska autorów poszczególnych wypowiedzi nadawały tekstom, ale przede wszystkim sądom w nim zawartym, wysoką rangę. Osoby te legitymizowały w wymiarze naukowym, prawnym, a nawet emocjonalnym przedsięwzięcia różnego rodzaju, zmierzające do przekonania o słuszności decyzji włączających cały teren Spiszu i Orawy do Rzeczypospolitej. Wśród piszących do numeru czwartego „Ziemi” znaleźli się członkowie Polskiego Towarzystwa Krajoznawczego i Polskiego Towarzystwa Tatrzańskiego, na przykład: Władysław Semkowicz, historyk; Juliusz Zborowski, dyrektor muzeum Tatrzańskiego w Zakopanem; Wacław Olszewicz, historyk kultury; pisarze: Mieczysław Świerz i Jan Wiktor; taternicy: Kazimierz Sosnowski czy już wymieniony Świerz. W artykułach tworzących numer, które z racji wykształcenia, pasji autorów były poświęcone konkretnej problematyce, na przykład topografii, geologii czy historii turystyki, można zauważyć podobne podejście do opisu krajobrazu jak w przypadku Bułhaka. Po pierwsze, było to podejście holistyczne, a więc traktujące przestrzeń wieloskładnikowo, ale nie tylko jako prostą sumę elementów, lecz także jako całość, w której zachodzą procesy między na przykład przyrodą a ludźmi. Dlatego w tych wypowiedziach wszelkie zmiany ingerujące chociażby w przebieg granic interpretowano jako pogwałcenie odwiecznych praw natury i jednocześnie praw człowieka.

Kazimierz Sosnowski w artykule Nieco z geografii i turystyki Spisza i Orawy celowo skoncentrował się na problematyce topografii i orografii, zaznaczając:

gdy staniemy na Giewoncie, na Babiej Górze albo na Turbaczu w Gorcach nowotarskich. Patrzącemu stąd na rozścielony w dole, widoczny jak na dłoni, wielki szmat ziemi z całą siłą narzuca się uwaga, że pocięcie go politycznymi granicami na trzy oddzielne krainy jest czymś nienaturalnym, jest jakimś gwałtem przeciw jego przyrodzonym warunkom. Dziecko nawet zauważy, że jest to jeden kraj, którego naturalną granicę południową mogą być tylko Tatry, tak jak to było pierwotnie [... $]^{12}$.

12 K. Sosnowski, Nieco z geografii i turystyki Spisza i Orawy, „Ziemia” 6, 1920, nr 4, s. 100. 
W przytaczaniu argumentów na poparcie praw Polski do tych obszarów Sosnowski powoływał się na prawa przyrody, prawa ludzkie, a nawet prawa boskie, których źródłem, jego zdaniem, była polska tożsamość rodzimych mieszkańców tej ziemi. Owi rdzenni mieszkańcy, jak podkreśla autor, posługując się językiem polskim, kultywując tradycje polskie, nadali tej krainie, we wszystkich jej wymiarach, znamię polskości. Fragmenty poświęcone krajobrazowi górskiemu zbudowane zostały z tego rodzaju środków artystycznych, które można odnaleźć w wypowiedziach słownych Bułhaka. Wyjątki te nie były próbą wiernego odzwierciedlenia elementów krajobrazu górskiego, a zapisem emocji towarzyszących obcowaniu z przyrodą ożywioną i nieożywioną tego konkretnego regionu. Wędrówki po Spiszu i Orawie, widoki, jakie rozpościerały się ze szczytów, hal, ewokowały odczucia oddane za pomocą stereotypowych, ale trafiających do szerokiego kręgu odbiorców zespołów epitetów, metafor i porównań. Spisz i Orawę Sosnowski nazywał „krajami górskimi z niewysłowionej piękności krajobrazem"13. Autor porównywał góry do księgi, a właściwie sposobu lektury. Tak jak obcowanie z niektórymi książkami może czytelnika znudzić, bo treść lektury jest mało interesująca, a akcja monotonna, tak i krajobraz, jego ukształtowanie, potrafi wprawić w nastrój określonego rodzaju:

Niziny — to książka przyrody do czytania rozwlekła, długa o ubogiej treści, góry — dla turysty najwspanialszy poemat natury — dla badacza — to książka ciekawa, zwięzła, stenograficznie pisana. Spośród cudów przyrody góry i morze największe na duszę ludzką wywierają wrażenie ${ }^{14}$.

Podstawą takiego porównania była cecha wspólna obiektów należących do dwóch różnych kategorii semantycznych: książka - kategoria „przedmiot”; góry — kategoria „natura”, „geologia”. Tertium comparationis to uczucie, jakie wywołuje czytanie i przebywanie na łonie natury. Krajobraz górski, jak treść interesującej książki, porusza zatem $\mathrm{w}$ takim stopniu, że w człowieku zachodzi przemiana, ponieważ doświadczane emocje przynależą do sfery sacrum — kształtują duszę ludzką. Sosnowski umiejętnie łączył różne style wypowiedzi: od naukowego, przez publicystyczny, do artystycznego (literackiego). Używał słownictwa specjalistycznego, typowego dla geologii, hydrologii. Przywoływał daty z historii interesującego go regionu i w ten naukowy dyskurs wplatał fragmenty, które ze względu na użyte środki stylistyczne przynależały do stylu literackiego. Całą wypowiedź natomiast podporządkował tezie, której sens oddawał następujący akapit: „Piękno tych gór ma być duchową strawą, ich turnie, słońce i powietrze zdrojem krzepkości fizycznej narodu. W rewindykację Tatr angażowany jest honor narodu i państwa autorytet!"15.

$\mathrm{W}$ podobnym, perswazyjnym tonie utrzymane były teksty dotyczące Spiszu i Orawy publikowane w tym samym okresie na łamach „Orlego Lotu”. Ze względu na adresata pisma - młodzież - szczególną wagę przywiązywano do waloryzowania opisów górskiego krajobrazu, co miało utwierdzać czytelników

\footnotetext{
13 Ibidem, s. 102.

14 Ibidem, s. 103.

15 Ibidem, s. 106.
} 
w przekonaniu nie tylko o wyjątkowości geograficzno-krajobrazowej tego regionu, ale przede wszystkim o przypisaniu tym ziemiom szczególnego znaczenia w najnowszych dziejach odrodzonej Rzeczypospolitej.

Władysław Semkowicz w publikacji Śladami kultury polskiej na Spiszu, opatrując każdy praktycznie toponim przymiotnikiem „polski”, porównuje Spisz i Orawę do najcenniejszego kamienia w koronie Piastów i Jagiellonów. Idealizacja funkcji polityczno-gospodarczej regionu w historii państwowości polskiej rozciągnęła się na walory krajobrazowe, przy czym autor zwracał uwagę na te elementy górskiego krajobrazu, które w sposób świadomy kształtował człowiek. Semkowicz wymieniał zamki, kościoły (na przykład zamek Lubowelski, kościoły w Kieżmarku, Popradzie, Lewoczy), mające cechy kultury polskiej, co — według autora - niepodważalnie dowodziło polskości tych ziem ${ }^{16}$.

W tym samym numerze wydrukowano artykuł Kazimierza Sosnowskiego Krajoznawczy rzut oka na Spisz i Orawę. Autor skoncentrował się w nim na postrzeganiu gór jako przestrzeni szczególnie pozytywnie oddziaływującej na młode osoby. Przebywanie w górach, obcowanie z nieskażoną przyrodą, wysiłek towarzyszący górskim wędrówkom - to wszystko sprzyjało, zdaniem Sosnowskiego, rozwojowi fizycznemu i moralnemu młodzieży. Kontakt z ludźmi zamieszkującymi tę przestrzeń, kierującymi się w życiu zasadami wysoce etycznymi, kształtował natomiast charakter i wzmacniał poczucie przynależności do wspólnoty, jaką jest naród. Przymioty te wyróżniały Spisz i Orawę. Jak pisał Sosnowski: „W bogactwa i niezwykłe piękności przyrody obfituje przede wszystkim Spisz. Aby temu dać wyraz, dość powiedzieć dwa słowa: Tatry i Pieniny"17.

Autorzy piszący do „Orlego Lotu” przypisywali górskim wyprawom i wycieczkom szczególnie ważne znaczenie w wychowaniu młodych pokoleń odrodzonej Rzeczypospolitej. Aby przekonać młodzież do podjęcia trudu zorganizowania takich wypraw, drukowano na łamach pisma wypowiedzi, które można uznać za ilustracje topografii emotywnej. W numerze drugim z 1922 roku Kazimierz Dobrowolski, etnolog z Uniwersytetu Jagiellońskiego, zamieścił relację z wyprawy do Doliny Białej Wody. Punktem wyjścia budowania sensualistycznego obrazowania przestrzeni z wykorzystaniem romantycznego wzorca kategorii wzniosłości były wrażenia wzrokowe, wśród których istotną rolę odgrywał kolor:

Od wschodu jonie poblask łuny. Nagle gorące promienie słońca starły z oblicza niebios blady róż. Świt w pełni. Głownie słoneczne płyną potokami od Spiskiej Magury na jaworzyńskiej polany lśniące krasą opalowych rós. Przed nami Murań z wierchami tkanymi szlakiem ogniowym, Murań skalny olbrzym. Nagle jego ściany jakby zalane morzem liliowych kosaćców - niżej ciemne plamy kosówki, a u stoków płaty smreków z wyzłacanymi czubami ${ }^{18}$.

\footnotetext{
16 W. Semkowicz, Śladami kultury polskiej na Spiszu, „Orli Lot” 1920, nr 3, s. 24-26.

17 K. Sosnowski, Krajoznawczy rzut oka na Spisz i Orawę, „Orli Lot” 1920, nr 3, s. 21.

18 K. Dobrowolski, Ze wspomnień jaworzyńskich, „Orli Lot” 1922, nr 2, s. 18.
} 
Krajobrazowi wizualnemu towarzyszył krajobraz dźwiękowy. Dobrowolski, wzorem romantyków, zwracał uwagę na doznania akustyczne ${ }^{19}$. Rejestrował dźwięki „wody biegnącej tu od Garłucha [Gerlacha — K.T.] władcy Tatr”, ,poszum rozhukanych, rwących wód" 20 , których oddziaływanie, podkreślone epitetami sygnalizującymi szybkie tempo, moc, ukształtowało materię skalną. Użyte metafory, rozbudowane epitety, słownictwo batalistyczne, środki animizujące składały się na kształt krajobrazu sensualistycznego, służącego idealizacji danej przestrzeni w wymiarze sakralnym. Fragment kończący artykuł Dobrowolskiego utrwalał w wyobraźni czytelników konkretną wizję przestrzeni, przede wszystkim w wymiarze emotywnym:

Niezapomniane widoki, niewygasłe nigdy w pamięci przeżycia... Tu w zetknięciu ze światem Teatr doznają ukojenia nasze tęsknoty za czymś nieznanym, pięknym, za jasnym jutrem, tęsknoty, co jak śnieżyczki pod bielą śniegu, kryją się w głębinach naszego serca. Tu czar gór w duszę płynący podnosi skrzydła do górnych lotów i zamierzeń ${ }^{21}$.

Apelatywny ton ostatniego zdania przywołuje skojarzenia ze słynnym Mickiewiczowskim wezwaniem z Pieśni Filaretów: „Mierz siły na zamiary/Nie zamiar podług sił”. Nie jest to przypadek, jeżeli wziąć pod uwagę koncepcje wychowawcze popularyzowane w dwudziestoleciu międzywojennym, a odzwierciedlające spory o charakterze ideologicznym. Upraszczając, ponieważ niniejszy artykuł ma inny cel, należy wskazać na dwie, konkurujące z sobą, aczkolwiek mające wiele wspólnych cech, wizje systemu wychowawczo-edukacyjnego w Rzeczypospolitej. Pierwsza została ukształtowana jeszcze na przełomie XIX i XX wieku pod wpływem działania Ligi Narodowej Romana Dmowskiego. Drugi model był elementem polityki sanacyjnej. Obydwa wzorce akcentowały podobne cechy pożądane u obywatela Rzeczypospolitej, takie jak: obowiązkowość, pracowitość, służba ojczyźnie i narodowi. Były to cechy przejęte między innymi z romantycznych i pozytywistycznych wzorców wychowania ${ }^{22}$. Nadrzędna funkcja, jakiej podporządkowano artykuł Kazimierza Dobrowolskiego z „Orlego Lotu”, to funkcja perswazyjno-propagandowa. W celu nakłonienia młodego czytelnika do zaakceptowania działań zmierzających do włączenia Spiszu i Orawy w granice Polski posłużono się: odpowiednią formą wypowiedzi, konstrukcją wypowiedzi oraz świadomie dobranymi środkami stylistycznymi. Już sam tytuł — Ze wspomnień jaworzyńskich — zwracał uwage na faktycznego bohatera tekstu, czyli region, o który toczono spór. Wspomnienie, jako relacja pamiętnikarska, wzmacniała wiarygodność przekazu. Innym elementem potwierdzającym rzetelność opisu i jednocześnie słuszność warstwy opiniotwórczej

19 E. Słoka, Romantyczna dolina. Część II, „Góry - Literatura - Kultura” 4, 2001, s. 115-116.

${ }^{20}$ K. Dobrowolski, op. cit., s. 18.

${ }^{21}$ Ibidem.

${ }^{22}$ Zob. K. Jakubiak, Idea wychowania obywatelskiego w polskiej myśli pedagogicznej przełomu XIX i XX wieku oraz okresu II Rzeczypospolitej, „Chowanna” 2 (11), 1998, s. 68; M. Strzelecki, Wizje wychowania społecznego w polskiej myśli politycznej lat 1918-1939, Bydgoszcz 2008, s. 113-141. 
wypowiedzi było nazwisko autora opatrzone tytułem naukowym. Artykuł rozpoczynał fragment poświęcony opisowi krajobrazu i zajmował połowę objętości całego tekstu. Rejestracja krajobrazu emotywnego wprowadzała czytelnika w określony nastrój, narzucając mu sposób percepcji oraz recepcji danej przestrzeni i jednocześnie przygotowując go do odczytania ukrytego sensu artykułu. Dobrowolski nie pominął w relacji elementu ludzkiego jako części opisywanego krajobrazu. Autor w emocjonalnym tonie pisał o gwarze, akcentując w niej obecność słów i zwrotów ze staropolszczyzny. Ubolewał nad nikłym poczuciem tożsamości narodowej mieszkańców Doliny Jaworzyńskiej, ale zwalniał ich z odpowiedzialności za tę sytuację. Za taki stan rzeczy winą obarczał natomiast wszystkich prowadzących działalność kulturowo-edukacyjną, ponieważ to oni — jego zdaniem — zapomnieli o ludziach mieszkających na kresach polskich ziem. Dobrowolski sugerował tym samym, że aktualne władze powinny spłacić zaciągnięty dług, nadrobić zaniedbania i wykorzystać wszystkie narzędzia, żeby przyłączyć Spisz i Orawę do Rzeczypospolitej. Artykuł kończył akapit, w którym Dobrowolski w podniosły sposób wyraził przekonanie o polskości spornych terenów: „O Jaworzynie od dawna roją się dobre sny. Przypadnie ona macierzy swej: Polsce [...]. Radośnie wszystkich powitają jaworzyńskie turnie, radośnie dzielić się będą swymi skarbami!"23. Wspomnienie Dobrowolskiego wydrukowano na początku numeru drugiego jako pierwszy tekst, co sygnalizowało czytelnikowi jego prymarne znaczenie i równocześnie wzmacniało siłę oddziaływania.

Ze wspomnień jaworzyńskich to kolejny z cyklu artykułów drukowanych na łamach „Orlego Lotu” poświęcony sprawie Spiszu i Orawy. Na początku sporu, w ostanich miesiącach roku 1919 i pierwszych 1920, kiedy zapadały decyzje o przynależności państwowej tych ziem, redakcja pisma, zgodnie z deklaracjami swojego organu założycielskiego, a także postulatami innych towarzystw, na przykład Polskiego Towarzystwa Tatrzańskiego, Towarzystwa Kresów Południowych, zalecała szczegółowe przedstawianie tej problematyki na zebraniach młodzieżowych kół PTK. W ten sposób zasięg oddziaływania tekstów publikowanych na łamach czasopisma poszerzał się o osoby, które nie musiały być czytelnikami „Orlego Lotu”, ale w większym lub mniejszym stopniu współpracowały z Towarzystwem.

We wszystkich wypowiedziach zamieszczonych w polskich pismach krajoznawczo-turystycznych ludność Spiszu i Orawy charakteryzowano jako element lokalnego krajobrazu, akcentując jej tożsamość polską; ewentualnie pisano o ambiwalentnym stosunku Spiszaków, Orawian do przynależności narodowej. W tym drugim przypadku jednak od razu przytaczano liczne argumenty, które miały przemawiać za polskością mieszkańców ziem spornych. Jedną z figur ułatwiających autorom taki sposób prezentowania Spiszaków i Orawian była figura wroga. Interesujące, że wrogami byli nie rdzenni mieszkańcy Spiszu i Orawy, sympatyzujący z Czechami, Słowakami czy wcześniej Węgrami, a przedstawiciele wymienionych nacji, niekoniecznie związani pochodzeniem lub zamieszkaniem ze spornym regionem. Wróg zatem to najczęściej bliżej nieokreślony Czech, Madziar, bezprawnie wyciągający

${ }^{23}$ K. Dobrowolski, op. cit., s. 19. 
ręce po tereny, do których nie miał praw. Jan Wiktor negatywne epitetował Czechów, starając się przekonać czytelników ,Ziemi”, że Czesi to okupanci Spiszu i Orawy, którzy wszystkich niepokornych rdzennych górali prześladowali, „,wlekli do więzień i obozów internowania", którzy szkalowali Polaków, rozpowszechniali kłamstwa, przedstawiając Polskę jako „kraj nędzy i żebraków”24. Na zasadzie kontrastu, manichejskiego podziału, po drugiej stronie sytuowali się Spiszacy i Orawianie, zwłaszcza ci uświadomieni, nazywani przez Wiktora „męczennikami i wojownikami świętej sprawy". Oni prowadzili mozolną pracę agitacyjną i stawali się symbolami ludu Spiszu i Orawy, który, jak zaznaczał autor, od wieków pielęgnował przywiązanie do języka polskiego i tradycji polskich. Owi rodzimi, lokalni działacze, „męczennicy sprawy", oddając wolność, a nawet życie za przekonania, uświęcali rodzinną ziemię. Mieszkaniec Orawy i Spiszu sportretowany przez Wiktora, ale także przez innych autorów wypowiedzi prasowych ogłaszanych w latach 1918-1922, przydawał regionowi znamion wyjątkowości. Przebywanie wśród ludu Spiszu i Orawy, poznawanie ich systemu aksjologicznego wywoływało podobne doznania jak kontakt z nieskalaną przyrodą. Ucieleśniali oni takie wartości, jak: uczciwość, wierność, skromność, oddanie sprawie, a więc te najważniejsze, wpisane w edukacyjno-wychowawczy wzorzec obywatela II Rzeczypospolitej.

W prasie codziennej, z racji pełnionej funkcji — w pierwszej kolejności informacyjnej — a także ze względu na specyfikę formalno-wydawniczą, czego konsekwencją było operowanie krótkimi formami wypowiedzi, w mniejszym stopniu spór o Spisz i Orawę ukazywano na tle prezentowanych szczegółowo argumentów natury historycznej czy kulturowej. Autorzy tekstów drukowanych w „Gwiazdce Cieszyńskiej” czy „Gazecie Podhalańskiej” zapoznawali swoich czytelników przede wszystkim z przebiegiem akcji dyplomatycznych, walk zbrojnych i działań lokalnych agitatorów. Piszący do prasy koncentrowali się zatem na czynniku ludzkim krajobrazu lokalnego, a do opisu używali środków identycznych jak autorzy wypowiedzi z czasopism krajoznawczo-turystycznych, chociaż były one mniej wyszukane stylistycznie. Czechów — pojedynczych działaczy czy całe grupy, jak na przykład oddziały czeskiej żandarmerii — charakteryzowano za pomocą słów będących nazwami człowieka godnego potępienia i pogardy. Dużą frekwencją cieszyły się takie określenia, jak: bojówki czeskie, tłuszcza, pijacy, złodzieje, kłamcy, indywidua spod ciemnej gwiazdy, bandyci, czeskie pachołki, dzicz czeska. Przedstawiciele organów polskich z kolei cechowali się spokojem, rozwagą, odwagą, godnością, zimną krwią. Rozstrzygnięcie Rady Ambasadorów z lipca 1920 roku jednoznacznie uznano za krzywdzące dla Polski, o czym świadczyły tytuły artykułów drukowanych na pierwszych stronach gazet wytłuszczoną i powiększoną czcionką, jak na przykład Nasza krzywda. W tekstach tych autorzy zwracali uwagę głównie na straty Polski w wymiarze gospodarczym, a jeżeli nawiązano do elementów krajobrazu naturalnego, to przede wszystkim w kontekście ekonomicznym. Ubolewano zatem nad utratą Doliny Białej Wody, leśnych terenów wokół Jaworzyny, źródeł w Połhorze, ponieważ, ze względu na

24 J. Wiktor, Poludniowe Kresy, „Ziemia” 6, 1920, nr 4, s. 99. 
potencjał turystyczny regionu, mógł on przynieść młodemu państwu polskiemu duże dochody, a miejscowej ludności zagwarantować podniesienie poziomu życia. Do zadań propagandowych wykorzystywano także wypowiedzi klasyfikowane do literackich. „Gazeta Podhalańska” w numerze trzydziestym z 25 lipca 1920 roku na pierwszej stronie wydrukowała wierszowany apel, napisany w stylu patetycznym, pod tytułem Do górali z Spisza, Orawy i Czacy, w którym to tekście biskup Władysław Bandurski upominał tytułowych adresatów:

Wy, szlachetnego konary korzenia, / A w żyłach waszych polska płynie krew. / Nie wierzcie kiedy wyzyskiem Was wabią, / Niech Was nie nęci tych migawek blask! / Oni Was z cnoty i z mienia ograbią, / Niedola Wasza, wrogów Waszych zysk. / Wy trwajcie stale przy Waszej Macierzy, / Strzeżcie świętości tych ojczystych gleb! / A sprawiedliwy Sąd Bóg Sam wymierzy, / Pokarmem Waszym będzie polski chleb! [... $]^{25}$.

Perswazyjność wypowiedzi słownych eksponujących motyw górskiego krajobrazu, zwłaszcza w czasopismach turystyczno-krajoznawczych, została wzmocniona przez dołączanie materiału ikonicznego. Szczególne wrażenie na czytelniku tych pism, który niejednokrotnie nie miał okazji na własne oczy zobaczyć gór, robiły fotografie. Bułhak wskazywał czytelnikom „Ziemi” możliwości, jakie stwarzała sztuka fotografii, również w zakresie oddziaływania na odbiorcę. W przywołanym już numerze dziewiątym „Ziemi” z 1912 roku zamieszczono dwanaście zdjęć krajobrazu, przy czym tylko dwa prezentowały góry (Tatry i pasmo Czarnohory). Jedno z nich przedstawiało fragment szlaku z Kalatówek do wywierzysk Bystrej, a wykonawcą zdjęcia był Jan Małachowski - malarz, fotograf, taternik, który w latach międzywojennych opublikował dwa albumy z fotografiami Tatr. Zdjęcia z dziewiątego numeru pisma, oprócz tych autorstwa Bułhaka, miały za zadanie tylko ilustracyjnie dopełnić słowne wypowiedzi. W numerze poświęconym Spiszowi i Orawie zamieszczone fotografie nie tylko ilustrowały warstwę słowną, lecz także wzmacniały funkcję propagandową poszczególnych wypowiedzi. Sama liczba zdjęć jest już imponująca. Dwadzieścia trzy fotografie przedstawiały krajobraz naturalny, miejski, typy ludzkie, konkretne zabytki architektury, dzieła sztuki; tematycznie wszystkie dotyczące Spiszu i Orawy. Wśród autorów zdjęć znalazł się między innymi Walery Goetel, który aktywnie uczestniczył w agitacji na rzecz przyłączenia Spiszu i Orawy oraz całego Podhala do Polski, kierując pracami Polskiego Komitetu Plebiscytowego Spisko-Orawskiego. Na uwagę zasługuje zwłaszcza jedno zdjęcie Goetla zamieszczone na łamach „Ziemi”, ukazujące krajobraz z Orawicą i okolicznymi wzgórzami widoczny z okien wieży zamku Orawskiego. Interesująca jest kompozycja tego zdjęcia, ponieważ fotograf ujął w kadrze kształt okna z typowym dla gotyku ostrołukiem. Okno było ramą dla rozpościerającego się z niego widoku, na wzór klasycznego obrazu, którego rama zamyka płótno. Zdjęcie to można zatem interpretować jako pejzażowe, topograficzne, tylko rejestrujące wyznaczniki danej przestrzeni, a jednocześnie można je uznać za pejzaż

25 W. Bandurski, Do górali z Spisza, Orawy i Czacy, „Gazeta Podhalańska” 1920, nr 30, s. 1. 
fantastyczny, a więc powstały pod wpływem emocji, przeżyć, których źródłem był nie tylko postrzegany krajobraz, ale również doświadczenie wynikające z wiedzy, na przykład historycznej, nałożone na owe wzrokowe postrzeganie tu i teraz. Inne zdjęcia zamieszczone w tym numerze, wykonane na przykład przez Eugeniusza Stercułę - aptekarza, polskiego działacza, miłośnika fotografii mieszkającego w Jabłonce, przedstawiały typy ludzkie Orawian (fotografie te do dzisiaj są cennym materiałem etnograficznym), zabytki architektury sakralnej, ludowej. Fotografie Strecuły wzbogacały warstwę faktograficzną tekstów poświęconych kulturze materialnej i duchowej mieszkańców Orawy i Spiszu. Należy jednak pamiętać, że cały numer czwarty „Ziemi” z 1920 roku podporządkowano hasłom: „Brońmy polskiego Spisza i Orawy! Brońmy zagrożonych Tatr!”, wydrukowanym na zewnętrznych okładkach numeru. Wszystkie wypowiedzi składające się na ten zeszyt, w tym wizualne, zostały więc podporządkowane założonej z góry tezie interpretacja owych fotografii została zatem ukierunkowana.

\section{Podsumowanie}

Wiesław Władyka w opracowaniu syntetycznym na temat czasopism dwudziestolecia międzywojennego napisał, że „były one zwierciadłem kłopotów ekonomicznych, społecznych i perturbacji politycznych Rzeczypospolitej" ${ }^{26}$. Biorąc pod uwagę wybrane do analizy pisma, należy zgodzić się z tym stwierdzeniem. Autorzy sięgający po to najpopularniejsze na początku XX wieku medium komunikacyjne stosowali różne zabiegi, figury retoryczne, środki stylistyczne i kompozycyjne, aby przekonać czytelnika do swoich tez, narzucić mu poglądy nie tylko w kwestiach politycznych, historycznych, ekonomicznych, lecz także skłonić go do ukierunkowanej recepcji tekstu kultury, jakim jest między innymi krajobraz. Kontynuacją tego sposobu ujmowania krajobrazu na łamach prasy były publikacje $\mathrm{z}$ lat trzydziestych XX wieku, kiedy na przykład popularyzowano wspomniany już Program Fotografii Ojczystej ${ }^{27}$.

\section{Bibliografia}

Bandurski W., Do górali z Spisza, Orawy i Czacy, „Gazeta Podhalańska” 1920, nr 3.

Bułhak J., Krajobraz i fotografia, „Ziemia” 3, 1912, nr 9.

Czarnowski A., Leopold Węrzynowicz — organizator krajoznawstwa wśród młodzieży, Warszawa 1987.

Dobrowolski K., Ze wspomnień jaworzyńskich, „Orli Lot” 1922, nr 2.

26 W. Władyka, Prasa Drugiej Rzeczypospolitej, [w:] J. Łojek, J. Myśliński, W. Władyka, Dzieje prasy polskiej, Warszawa 1988, s. 92.

${ }^{27}$ Interesujące w tym kontekście są artykuły Mariana Antoniego Wieczorka na temat fotografii górskiej publikowane na łamach „Nowości Fotograficznych” w latach 1930-1935. 
Heska-Kwaśniewicz K., ,, Wyznanie narodowe Śląska”. Teksty literackie i paraliterackie w drukach okresu powstań i plebiscytu na Górny Śląsku, Katowice 1999.

Jakubiak K., Idea wychowania obywatelskiego w polskiej myśli pedagogicznej przełomu XIX i XX wieku oraz okresu II Rzeczypospolitej, „Chowanna” 2 (11), 1998.

Kulwieć K., Na otwarcie wystawy, „Ziemia” 3, 1912, nr 11.

Semkowicz W., Śladami kultury polskiej na Spiszu, „Orli Lot” 1920, nr 3.

Skowron W., Krajobraz polski w centrum zainteresowania Polskiego Towarzystwa Krajoznawczego - wystawy fotograficzne, „Ziemia” 61, 2010.

Słoka E., Romantyczna dolina. Część II, „Góry - Literatura - Kultura” 4, 2001.

Sosnowski K., Krajoznawczy rzut oka na Spisz i Orawe, „Orli Lot” 1920, nr 3.

Sosnowski K., Nieco z geografii i turystyki Spisza i Orawy, „Ziemia” 6, 1920, nr 4.

Strzelecki M., Wizje wychowania społecznego w polskiej myśli politycznej lat 1918-1939, Bydgoszcz 2008.

Szymanowicz M., Topografia sukcesu, „Artium Quaestiones” 17, 2006, https://repozytorium.amu. edu.pl/handle/10593/11099.

Szymanowicz M., W poszukiwaniu ,narodowości w fotografice”, „Artium Quaestiones” 28, 2017.

Wiktor J., Poludniowe Kresy, „Ziemia” 6, 1920, nr 4.

Władyka W., Prasa Drugiej Rzeczypospolitej, [w:] J. Łojek, J. Myśliński, W. Władyka, Dzieje prasy polskiej, Warszawa 1988.

Wójcik W.A., „Ziemia”. Od PTK do PTTK, „Ziemia” 61, 2010.

Wystawa „Krajobraz polski”, „Ziemia” 2, 1911, nr 23. 